\title{
Baroja como materia de sus libros: para una lectura de El árbol de la ciencia (1911) en clave autobiográfica
}

\author{
Baroja as the Subject Matter of his Books: For an \\ Autobiographical Reading of El árbol de la ciencia (1911)
}

\author{
Francisco Fuster García \\ Universidad de Valencia
}

\section{RESUMEN}

El objetivo de este trabajo es analizar las características de la literatura autobiográfica barojiana y comprobar si existen argumentos suficientes para afirmar que El árbol de la ciencia es quizá la novela más autobiográfica de Pío Baroja. Para ello, y tras repasar lo dicho por los estudiosos sobre el autobiografismo barojiano, me centraré en el estudio de los personajes autobiográficos de El árbol de la ciencia e intentaré situar esta novela dentro de su «espacio autobiográfico». Por último, propondré una posible interpretación del doble valor que atribuimos al protagonista de la novela, Andrés Hurtado, como personaje autobiográfico y como símbolo generacional de la juventud española que vivió la llamada «crisis de fin de siglo».

Palabras Clave: Pío Baroja, El árbol de la ciencia, novela autobiográfica, memorias, espacio autobiográfico, Andrés Hurtado, Iturrioz.

\begin{abstract}
The aim of this paper is to analyze the characteristics of Barojian autobiographical literature and to check if there are enough arguments to state that El árbol de la ciencia is Pío Baroja's most autobiographical novel. For that purpose, and after going over the scholar's theories about the autobiographical side of Barojian literature, the article focuses on the study of autobiographical characters in El árbol de la ciencia and attempts to place this novel within its «autobiographical space». Lastly, it suggests a possible interpretation of the double value that we attribute to the main character of the novel, Andrés Hurtado, as an autobiographical character and as a generational symbol of the Spanish youth that lives the end-of-century crisis.
\end{abstract}

Key words: Pío Baroja, El árbol de la ciencia, autobiographical Novel, Memoirs, Autobiographical Space, Andrés Hurtado, Iturrioz. 


\section{EL AUTOBIOGRAFISMO BAROJIANO}

En el prólogo a la edición de las Obras Completas de Pío Baroja publicadas por Galaxia Gutenberg y Círculo de Lectores, José-Carlos Mainer hacía una oportuna y sintomática advertencia al subrayar la necesidad de «sacudirse toda idea de autobiografismo mecánico que ve en cada texto de Baroja y en cada uno de sus personajes aquello que los exégetas suelen llamar «la encarnación de las ideas del autor»...» (Mainer, 1997: 13). Era un toque de atención y un aviso al rigor interpretativo del lector o estudioso de la obra barojiana, fundado en la existencia de una ingente bibliografía que ha venido señalando-ya en vida del autor- el carácter autobiográfico de toda la producción literaria de del novelista vasco. En este sentido, es tal el volumen de autores y estudios que han subrayado esta característica, la mayoría de las veces con razón y otras menos sin ella, que es muy posible que los textos de Baroja hayan sido víctimas en más de una ocasión de ese excesivo celo del lector al que Umberto Eco llamó «sobreinterpretación».

En efecto, si en algo ha coincidido la práctica totalidad de la crítica barojiana ha sido en destacar la omnipresencia del escritor de San Sebastián en todos y cada uno de los textos que dio a la imprenta; resulta difícil encontrar una monografía que no dedique un apartado o capítulo al ubicuo asunto del autobiografismo que imbuye e impregna muchas páginas de la producción barojiana. De Baroja se ha destacado su «incontinencia autoconfesional» (De Torre, 1969: 97) y de su obra que es una «oscura y monumental autobiografía» (Sánchez-Ostiz, 2006: 13) o que «está constituida por ochenta volúmenes de Memorias, las Memorias de su vida secreta, de todos los hombres que él quisiera ser» (Torrente Ballester, 1965: 234). En la misma línea se han expresado un José Luis Abellán que ha hablado del «hecho evidentísimo de la presencia constante del autor en todas sus novelas, que las hace rezumar subjetivismo por los cuatro costados» (Abellán, 1973: 71), o un buen conocedor de la obra barojiana como lo fue Luis S. Granjel, quien también reparó en más de una ocasión en esta omnipresencia del autor en su obra:

En realidad, toda la obra barojiana es cual una gigantesca representación, desmesurada tanto por la diversidad de sus escenarios como por el número de sus personajes, entre los cuales transita, señera, una criatura singular, encarnación literaria de quien fraguó la tramoya y mueve los hilos que ponen en movimiento la escena; y todo en ella: los paisajes y los personajes, sus ideas y sus emociones, están vistos y relatados a través de ese personaje que no es nadie sino el propio Baroja... (Granjel, 1953: 139).

En efecto, el personaje protagonista o secundario de la novela barojiana ha sido el vehículo fundamental mediante el cual el autor ha ido filtrándonos sus opiniones y sus emociones; todos aquellos episodios, anécdotas y situaciones vividas por Baroja a lo largo de su existencia, han sido de una forma $\mathrm{u}$ otra noveladas y «revividas», con mayor o menor fidelidad al original, por 
ese ejército de personajes y tipos que transitan los lugares y los ambientes en los que se desarrolla la acción de su vasta obra literaria. En este sentido, cabe decir que, aunque no fuese Baroja el único escritor de su generación en hacerlo, sí que fue probablemente uno de los que más empleó este recurso, como él mismo no tuvo ningún reparo en reconocer en su «Prólogo casi doctrinal sobre la novela»: «¿Quiénes son los novelistas actuales que han podido crear tipos que lleven una vida independiente de su autor? ¿Quiénes son los que han pintado sombras que no son la proyección de sí mismos? Yo no conozco a ninguno» (Baroja, 1997-1999, I: 1152) ${ }^{1}$.

Como ya fue señalado por escritores y críticos en su día, coincido en que la mayoría de estos desdoblamientos fueron la manifestación de diferentes aspectos o facetas de su individualidad o de su vida pasada, pero también fueron una especie de existencias vicarias del propio Baroja, de recreaciones de aquellas otras vidas que el escritor imaginó, pero nunca llegó a vivir. Estos personajes autobiográficos son los más interesantes y, a juzgar por lo dicho - quizá un poco exageradamente- por parte de algún lector, son los únicos, pues resulta complicado hallar un personaje barojiano con cierta entidad o importancia que no posea algún rasgo que lo emparente directamente con su creador. Eso mismo apuntaba Gaziel en un artículo en el que periodista catalán insistía en la idea de que todos los personajes de Baroja se comportan como el propio Baroja, razón por la cual el lector no termina de diferenciarlos, no acaba de interiorizarlos:

\begin{abstract}
Ahora vamos a dar con el secreto que nos intrigaba. Los personajes de esas novelas no perduran, por la sencilla razón de que no son tales personajes, de que no tienen vida propia, ya que en el fondo de todas las obras barojianas no hay más que un solo personaje, que es el mismo Baroja, y un solo espíritu perdurable, que es el espíritu del mismo autor. [...] Todos los personajes de Baroja hablan de la misma manera: como habla Baroja. Todos piensan del mismo modo: como piensa Baroja. Todos obran como se le antoja a Baroja. El autor está constantemente detrás de ellos. Por eso cuando queremos evocarlos nos es imposible recordarles a ellos, y en cambio recordamos perfectamente a su autor (Gaziel, 1925).
\end{abstract}

Aunque en este trabajo voy a centrarme en los personajes autobiográficos de El árbol de la ciencia, especialmente en el caso de Andrés Hurtado, quisiera señalar ahora la existencia de algunos de estos personajes — citaré solo los más conocidos, por ser precisamente los más inequívocamente autobiográficos- presentes en diferentes novelas del autor. Nombrándolos por el orden cronológico de su aparición dentro de la producción barojiana, podemos considerar como total o parcialmente autobiográficos a los siguientes personajes barojianos: Fernando Ossorio, protagonista de Camino de perfección (1902);

${ }^{1}$ A partir de este momento, siempre que cite a Baroja lo haré siguiendo esta edición de sus Obras Completas (OC) dirigida por José-Carlos Mainer y publicada en dieciséis volúmenes por el Círculo de Lectores y la editorial Galaxia Gutenberg entre 1997 y 1999. 
César Moncada, protagonista de César o nada (1910); Andrés Hurtado, protagonista de El árbol de la ciencia (1911); Luís Murguía, protagonista de La sensualidad pervertida (1920); Jaun de Alzate, protagonista de La leyenda de Jaun de Alzate (1922); José Larrañaga, protagonista de la trilogía «Agonías de nuestro tiempo» (El gran torbellino del mundo, 1926; Las veleidades de la fortuna, 1927; y Los amores tardios, 1927); y Procopio Pagani, protagonista de El hotel del cisne (1946).

De todas estas novelas que he citado, considero que las más puramente autobiográficas son Camino de perfección, El árbol de la ciencia y La sensualidad pervertida. En las otras lo que hay es un personaje protagonista, alguna de cuyas facetas está más menos inspirada en el propio Baroja. En otras novelas que no cito, como Aventuras, inventos y mixtificaciones de Silvestre Paradox (1901), Las inquietudes de Shanti Andía (1910) y algunas otras, más que la identificación de Baroja con algún personaje lo que encontramos es la recreación de ambientes y lugares (los recuerdos de la Pamplona de su infancia en el caso de la primera o el ambiente marinero del San Sebastián que el escritor vivió durante su niñez en el caso de la segunda) de contenido también autobiográfico. Existen igualmente algunos personajes secundarios - aunque de un gran valor dentro de sus respectivas tramas, incluidos algunos de El árbol de la ciencia, como a continuación veremos- en los que también se pueden rastrear elementos o proyecciones de algún rasgo concreto de la personalidad de nuestro autor.

En el caso de algunas de estas novelas, como sucede por ejemplo con Aventuras, inventos y mixtificaciones de Silvestre Paradox, La sensualidad pervertida y, por supuesto, El árbol de la ciencia, el autobiografismo viene de alguna forma avalado por el conocido hecho del uso del texto de estas ficciones por parte del escritor como material para sus memorias. Baroja «corta y pega» de estas novelas aquellos fragmentos más fielmente autobiográficos y los inserta literalmente en sus memorias, Desde la última vuelta del camino, cambiando simplemente el nombre del protagonista por la primera persona. Sobre este aprovechamiento del material de las novelas volveré más adelante al hablar del «espacio autobiográfico» en la literatura barojiana.

Por lo que se refiere a cuál sea la naturaleza de este contenido autobiográfico de las novelas y los personajes de Baroja, también han existido distintas posturas, hasta el punto de que es posible hablar — como han hecho ya algunos autores - de varios tipos de autobiografismos dentro de la obra barojiana o de una tipología de personajes según su grado o nivel de identificación biográfica. Varios críticos han coincidido a la hora de hablar de una especie de «autobiografismo ideológico», en un intento de expresar que aquello que Baroja transmite a sus personajes es ante todo su ideología, no en el plano político, sino en el sentido más general que alude a sus ideas sobre la vida y su concepción del mundo. En esto parece pensar Azorín cuando escribía que «toda la obra novelesca de Baroja es una autobiografía intelectual» (Azorín, 
1918), Gerardo Ebanks cuando afirma que los personajes barojianos «no son más que proyecciones conceptuales e ideológicas del propio autor» (Ebanks, 1974: 281) o Granjel cuando se extiende sobre este punto para hablar de lo que él llama «trasfondo ideológico de sus relatos»:

El único elemento, entre los esenciales dentro de su manera de novelar, que Baroja no toma del mundo exterior son los comentarios y las opiniones, el trasfondo ideológico de sus relatos; para exponerlos, recurre siempre nuestro novelista a una misma argucia: vacía a algún personaje de todo lo que no sea su mera figura exterior para rellenarlo después con sus personales ideas; en ocasiones, estos mismos personajes son asimismo los llamados a vivir, revivir, trozos de su propia biografía (Granjel, 1953: 140-141).

En El pacto ambiguo, Manuel Alberca dedica un subapartado a la novela autobiográfica de Baroja en el que establece hasta tres posibles tipos de autobiografismo en la obra del novelista vasco, según sea mayor o menor el grado de identificación entre el personaje literario y la persona del autor. Un primer tipo de novela autobiográfica en Baroja se caracterizaría por el hecho de que:

[...] la historia novelesca se alimenta de manera precisa de la trayectoria vital del autor: su experiencia y formación, los lugares en los que vivió, determinados acontecimientos personales e históricos que sirven de apoyo al relato son, debidamente transfigurados por la ficción, los mismos que constituyen las coordenadas vitales del autor. De este modo el novelista cuenta su vida bajo el disfraz de la ficción, escondiendo su historia lo suficiente para no poder ser identificado (Alberca, 2007: 121).

Alberca habla de novelas —en plural— «específicamente autobiográficas», pero únicamente cita el ejemplo de La sensualidad pervertida, y lo hace basándose en los rasgos que comparte el protagonista de la novela con Baroja y en el hecho cierto de que en varios pasajes de sus memorias el novelista reconoce el carácter autobiográfico de esta novela ${ }^{2}$ e incluso copia literalmente algún fragmento, haciéndolo pasar por texto memorialístico.

El segundo tipo de autobiografismo presente según este autor en la obra de Pío Baroja sería el representado por aquellos «relatos de un menor calado autobiográfico en el sentido de que no proyectan ni aspiran a proyectar una imagen de sí mismo» (Alberca, 2007: 123). Se trata de textos que incluyen «marcas vitales del autor en su obra, que podríamos denominar, sin ninguna retranca peyorativa, "autobiografismo anecdótico"» (Alberca, 2007: 123); dentro de este grupo entrarían novelas como Aventuras, inventos y mixtificacio-

${ }^{2}$ En «Familia, infancia y juventud», segundo volumen de Desde la última vuelta del camino, escribe Baroja: «De la vida infantil de Pamplona he hablado en dos novelas: en $L a$ sensualidad pervertida, libro en gran parte autobiográfico, con muchas cosas disfrazadas y cambiadas, y en Silvestre Paradox» (Baroja, 1997-1999, I: 409). Tres páginas después, insiste en que se trata de una novela autobiográfica (Baroja, 1997-1999, I: 412). 
nes de Silvestre Paradox, en la que Baroja recrea el ambiente callejero de su infancia en Pamplona; otras como Zalacaín el aventurero o El mayorazgo de Labraz, en las que es el recuerdo de determinadas personas lo que subsiste en forma de personajes novelescos secundarios; y, por último, novelas como Los últimos románticos o El sabor de la venganza, en la que son los espacios urbanos o las casas, los elementos extraídos de la experiencia vital y los recuerdos del autor.

Un tercer tipo de autobiografismo barojiano establecido por Alberca sería lo que él considera como un autobiografismo «de carácter ideológico o idiosincrático, por el cual la ideología y el talante del creador inspira los discursos o actitudes de los personajes» (Alberca, 2007: 124). Para este especialista en literatura autobiográfica, «es posible que quepa considerar buena parte de la obra novelística de Baroja bajo este tipo de autobiografismo», y cita como ejemplos más notables de este tercer tipo El árbol de la ciencia, Camino de perfección y Las noches del Buen Retiro.

Aunque estoy de acuerdo en líneas generales con este planteamiento y comparto la idea de que no en todas las novelas de Baroja que podemos clasificar como autobiográficas el nivel de intensidad de este autobiografismo es equiparable, disiento en el caso concreto de El árbol de la ciencia. Convengo con Alberca en que se trata de una novela que cumple con ese «autobiografismo ideológico» — con el sentido de expresar a través del personaje protagonista las ideas del autor - al que ya me he referido antes. Sin embargo, y aplicando el criterio usado por el mismo Alberca, creo que El árbol de la ciencia también cabe perfectamente, junto a La sensualidad pervertida, en ese primer grupo de novelas a las que el autor concede el valor de «específicamente autobiográficas». Al margen de que considero que el contenido autobiográfico de la novela es igual o superior al presente en La sensualidad pervertida, aunque esto sea un juicio personal y subjetivo, difícil de cotejar o de medir, el otro criterio empleado por Alberca para identificar a esa otra novela como «específicamente autobiográfica» es, como he dicho, el del reconocimiento explícito de ese autobiografismo por parte de Baroja. Esto mismo es lo que sucede en el caso de $E l$ árbol de la ciencia, como corrobora el propio Baroja en unas líneas de Juventud, egolatría (un ensayo de signo completamente autobiográfico) solamente seis años después de la publicación de El árbol de la ciencia: «En mi novela El árbol de la ciencia he pintado una contrafigura mía, dejando la parte psicológica y cambiando el medio ambiente del protagonista, la familia y alguna otra cosa» (Baroja, 1997-1999, XIII: 398).

Igualmente, al recordar en esta misma obra las figuras de algunos de sus profesores en la facultad, cita la novela como el lugar donde ha dicho la verdad sobre ellos y la fuente donde se puede encontrar su opinión: «Entre los profesores, uno que se creía un pedagogo, y un pedagogo genial, era Letamendi. En el libro citado, El árbol de la ciencia, he dicho lo que me parecía tal profesor, que tenía cierto talento de orador y de literato» (Baroja, 1997-1999, XIII: 399). 
Pero además, y por si estos dos pasajes no fueran suficientes, también en sus memorias volverá a citar Baroja el caso de El árbol de la ciencia, dejando claro su condición de novela autobiográfica y refiriéndose a ella como una «recapitulación»:

El árbol de la ciencia es, entre las novelas de carácter filosófico, la mejor que yo he escrito. [...] Hay en ella una visión de la vida de tiempos pasados, una recapitulación. Aquí aparecen los compañeros de estudio de la carrera, el hermano Juan, tipos de bohemios extraños y algunas muchachas conocidas (Baroja, 19971999, I: 933).

Se entiende con ello, o al menos así lo interpreto yo, que al hablar de «recapitulación» se refiere Baroja al hecho de que El árbol de la ciencia es una novela autobiográfica en la que repasa su vida anterior. Hay que tener en cuenta que, si nuestro autor escribe la novela en el año 1909 y la termina de corregir en 1911, como he argumentado en mi tesis doctoral ${ }^{3}$, lo hace con 36 años, justo en el período luego reconocido como el de su plena madurez literaria. Esa es la edad que tenía Baroja durante todo el año de 1909 (hasta el 28 de diciembre cuando cumple los 37); por eso, al hablar del El árbol de la ciencia como de una novela que contiene una «visión de la vida de tiempos pasados», se refiere evidentemente, y como especifica después, a su juventud y su época como estudiante de Medicina. No en vano es justamente ese el período de su vida más fielmente reflejado en la novela. Por todo esto y por el hecho de que en sus memorias también reproduce fragmentos enteros del texto de El árbol de la ciencia (sobre todo de la primera de las siete partes de la novela, cuyas descripciones encontramos textualmente reproducidas en Desde la última vuelta del camino), considero que la novela está debería incluirse también en el primero de los tres tipos de autobiografismo barojiano que establece Alberca en su clasificación.

De este repaso a lo dicho por la crítica sobre el autobiografismo en la obra de Baroja se deduce como primera conclusión la existencia en la obra barojiana de varios personajes que presentan como rasgo más evidente el hecho de ser trasuntos o contrafiguras del escritor, lo que confiere al conjunto de su obra ese título de magna autobiografía y la dota, como vieron muy bien algunos autores, de un elemento cohesionador únicamente comparable en importancia con ese estilo barojiano igual de omnipresente:

[...] sus obras nos dan la impresión de un caos de intuiciones, teorías y prejuicios sin norma ordenadora ni principio rector. Las únicas normas serían siempre de tipo negativo en cuanto a una estructura lógica se refiere: sinceridad y anarquismo. Y, sin embargo, tiene la obra de Baroja una unidad acaso más sólida que la de cual-

\footnotetext{
${ }^{3}$ Fuster García, Francisco. España, fin de siglo: «El árbol de la ciencia», de Pío Baroja. Tesis doctoral inédita, leída el 7 de marzo de 2012 en el Departamento de Historia Contemporánea de la Universidad de Valencia.
} 
quier escritor, porque, en definitiva, toda ella no es sino una proyección de su propio yo (Del Río y Benardete, 1946: 202).

Queda claro también, como he documentado, que Baroja así lo reconoció en su día y que, gracias precisamente a este carácter autobiográfico de sus novelas y al cotejo que de sus informaciones podemos hacer en sus memorias, en la vasta obra barojiana se crea un rico e interesante «espacio autobiográfico». Este lugar de diálogo y cruce de referencias entre realidad y ficción, entre memorias y novela, es el que hace del conjunto de la obra barojiana, y de El árbol de la ciencia en particular, un magnífico testimonio para conocer no sólo la época de la crisis de fin de siglo en España, sino también, y especialmente, las sensaciones e impresiones precisas que un individuo particular - Baroja en la realidad histórica española y Andrés Hurtado en el contexto creado por el escritor para la novela- pudo experimentar en aquella situación de crisis y pérdida de valores que vive la España finisecular.

\section{EL ÁRBOL DE LA CIENCIA: NOVELA AUTOBIOGRÁFICA}

Una primera lectura de la bibliografía existente sobre El árbol de la ciencia podría ser suficiente para convencer al lector o al investigador de la naturaleza autobiográfica de la novela. De hecho, en la mayoría de los trabajos publicados por los críticos que han hablado del autobiografismo barojiano, no es nada raro encontrar citada El árbol de la ciencia como ejemplo paradigmático de novela autobiográfica escrita por Baroja. Se ha hablado de ella como de una «biografía espiritual de Baroja» (Ebanks, 1974: 100) y se la ha puesto como ejemplo de ese «autobiografismo ideológico» del que ya he hablado (Alberca, 2007: 124; Bretz, 1979: 376). Sergio Beser ha escrito sobre la importancia que tiene «el material previamente vivido, junto con ambientes y personajes tratados directamente» en el conjunto de la obra del narrador vasco, pero precisando en relación con nuestra novela que, «aunque esto ocurre en otras novelas barojianas, en ninguna alcanza parecida importancia» (Beser, 1983: 87-88).

En el caso del personaje protagonista, Andrés Hurtado, la lectura de la novela y el cotejo con las memorias de Baroja convence al lector poco informado sobre el hecho evidente de que estamos frente a un trasunto de Baroja, en concreto del Baroja joven: el estudiante que hizo la carrera de Medicina en Madrid y durante algunos años en Valencia. El primero en confirmarlo es el propio Baroja, quien en esos dos pasajes que ya he citado así lo reconoce. Primero en Juventud, egolatría, cuando nos dice que «en mi novela El árbol de la ciencia he pintado una contrafigura mía» (p. 398, XIII); y más tarde en sus memorias, cuando habla de la novela como de «una visión de la vida de tiempos pasados, una recapitulación» (p. 933, I) y cita aquellos elementos y 
vivencias de su juventud — «los compañeros de estudio de la carrera, el hermano Juan, tipos de bohemios extraños y algunas muchachas conocidas»- que luego son revividos por Andrés Hurtado en la novela, con esos cambios en el «medio ambiente del protagonista, la familia y alguna otra cosa», a los que alude el autor en Juventud, egolatría. En este sentido, y aceptando que estas afirmaciones se hacen en textos - estos sí- totalmente autobiográficos y no ficcionales, leídos en función de un «pacto autobiográfico» entre autor y lector, me parece absurdo negar la evidencia de que, efectivamente, la razón más poderosa para hablar de El árbol de la ciencia como de una novela autobiográfica reside en el hecho de que su protagonista no es otra cosa que la encarnación literaria, la versión en la ficción, de la persona y la personalidad del autor durante una fase de su vida.

Dicho esto, me interesa rescatar ahora lo defendido por parte de algunos autores que han afirmado, en un juicio que suscribo, que esta presencia del pensar y el sentir de Baroja concierne, además de al protagonista de la novela, al personaje que comparte con este las mayores dosis de protagonismo: el doctor Iturrioz.

En su clásico estudio sobre la presencia de Nietzsche en la literatura española contemporánea, Gonzalo Sobejano dedica un importante capítulo a la influencia del filósofo alemán en Baroja. Al detenerse en el análisis de $E l$ árbol de la ciencia, concluye que tanto en el personaje de Andrés Hurtado como en el de Iturrioz encontramos elementos procedentes del pensamiento del autor. La diferencia entre ambos radica en que, mientras el primero se inspira en la filosofía de Schopenhauer absorbida por Baroja, el segundo es un personaje de raíz puramente nietzscheana; de hecho, en el caso de Iturrioz, Sobejano retrocede tres años en la producción barojiana y sostiene que ya en La dama errante (1908) - la novela en la que Iturrioz aparece por primera vez como un personaje secundario - nos encontramos ante un personaje autobiográfico: una contrafigura del autor que entronca con el pensamiento de Nietzsche y que ejerce de «portavoz de Baroja» (Sobejano, 2004: 368-369).

Para Ángel M. Vázquez-Bigi, todas aquellas lecturas de la novela que reducen el contenido autobiográfico al personaje protagonista son simplificadoras ya que según su opinión, «tanto en Iturrioz como en Andrés podemos identificar facetas del espíritu de Baroja y etapas de su desarrollo — toda identificación con Andrés basada en contenido autobiográfico es imperdonablemente simplista—» (Vázquez-Bigi, 1968: 51). Sin ser tan tajantes, pero expresándose en la misma línea de distribuir el autobiografismo entre los dos personajes, algunos de los estudiosos de la obra barojiana han hablado de Andrés Hurtado e Iturrioz como de «dos aspectos diferentes, pero complementarios de la personalidad de Baroja» (Durán, 1972: 1), o han dicho que «los problemas filosóficos que preocupaban a Baroja están proyectados en Andrés - Baroja joven- y en Iturrioz — aroja maduro— (Basanta, 1980. 24). Esta hipótesis según la cual en El árbol de la ciencia tendríamos a dos personajes autobiográficos, uno como trasunto 
del Baroja joven, el estudiante de Medicina, y otro como paralelo ficcional del Baroja mayor, del hombre maduro, es quizá la que ha contado con más adeptos. En un libro derivado de su tesis doctoral, José Miguel Fernández Urbina habla de El árbol de la ciencia como de «una autobiografía solapada de la juventud y de la primera y última experiencia de Baroja como médico, aunque en realidad hay dos Barojas en la novela: el joven Andrés, inicialmente optimista, vigoroso, que desea implicarse en el entorno, y su tío Iturrioz, individuo adulto, escéptico, nihilista..., talante hacia el que confluye el sobrino a medida que madura» (Fernández-Urbina, 1998: 185). Y algo parecido defiende Isabel Criado cuando habla del problema social plasmado por el autor en un personaje protagonista que se debate entre el enfrentamiento y la aceptación social (aunque acabe suicidándose y anulando con ello el debate) y que la autora interpreta en clave autobiográfica como el debate interno de un Baroja que oscila «entre una integración masoquista - Hurtado, su contrafigura joven- y la destrucción sádica —-Iturrioz, su experiencia madura-»(Criado, 1974: 323).

Algún autor ha insinuado incluso la posibilidad de una tercera figura, que no sería tanto un personaje autobiográfico, como lo puedan ser Andrés Hurtado e Iturrioz, cuanto un vehículo o medio usado por Baroja para expresar sus ideas sobre un tema concreto. Me refiero al personaje de Lulú, de quien se ha dicho que «tiene de don Pío su sentido moral de la lealtad por encima de todo» (Medrano, 2006: 325), y que su mayor interés con vistas a descubrir el trasfondo autobiográfico de la novela son «sus cualidades morales e intelectuales, y la forma en que Baroja expresa, a través de los episodios por ella protagonizados, algunas de sus ideas acerca del matrimonio, la mujer y las relaciones entre los sexos» (Salazar, 1994: 282). En definitiva, se trataría más bien del uso de un personaje importante de la novela en el que se plasmaría ese «autobiografismo ideológico» barojiano del que ya he hablado.

Por otra parte, y como expresaron en alguna ocasión Baroja y alguno de sus familiares más cercanos, existe una multitud de personajes de la novela que no son autobiográficos, pero sí que fueron elaborados por el autor a partir de una persona a la que conoció en la vida real. Una de las personas que dio su opinión sobre este asunto fue Carmen Baroja, que en sus memorias elaboró una lista con algunas posibles identificaciones entre personajes de la ficción y personas del entorno vital de Baroja. Algunas de estas identificaciones pueden ser contrastadas con otras versiones; otras son originales de la hermana del escritor y su certeza resulta imposible de verificar:

En El árbol de la ciencia, que describe su vida de estudiante, aparecen Montaner (Riudavets), Aracil (Venero), Massó (Ruiz Contreras), Lamela (Linares), Sañudo (Alloza), Iturrioz (el primo de mi madre, Justo Goñi).

El padre del protagonista es un poco mi suegro Eduardo Caro y su manera de vivir en familia. Margarita, la hermana mayor, recuerda a mi madre, y yo soy un poco Luisito. La enfermedad de éste es la de mi hermano Darío. Pío describe el huerto de Burjasot y algo de la casa de la calle de Samaniego, de Valencia (Baroja, 1998: 198). 
Aunque en el caso de algunos de ellos esta relación no quede del todo clara, en otros resulta evidente el paralelismo y no es difícil buscar en las memorias o en los escritos autobiográficos de Baroja el posible modelo de cada uno de estos tipos literarios. Pensando en esta cantidad de personajes que remiten a personas y de situaciones que recuerdan a episodios vividos por el autor, se puede entender que Sánchez-Ostiz haya hablado de El árbol de la ciencia como de un roman à clèf, de «una novela en clave, casi más que claramente autobiográfica, porque como no sabremos cuáles son los episodios vividos y cuáles los imaginados, la duda resulta forzosa» (Sánchez-Ostiz, 2006: 148). Sin embargo, consideramos que más que un roman à clèf al uso, esta obra de Baroja es sencillamente una novela autobiográfica en la que - eso síabundan los personajes inspirados en la vida privada del escritor: familiares y amistades que en la ficción conservan los rasgos de su personalidad y a los que se les cambia el nombre propio. Como explica Pura Fernández tomando como modelo la novela de Alphonse Daudet Le nabab (1877), la novela en clave decimonónica se caracteriza fundamentalmente por tres rasgos: «la inmediatez respecto del período histórico evocado; la incorporación al elenco de dramatis personae de relevantes protagonistas de la sociedad contemporánea; y la alusión a episodios concretos que han suscitado el interés de la opinión pública» (Fernández, 2005: 104). En El árbol de la ciencia se da la primera de estas condiciones y hasta cierto punto la tercera, pero de ningún modo la segunda. Existe inmediatez porque la novela es de 1911 y el contexto histórico que recrea es del fin de siglo; aunque no sean abundantes, también hay alusiones específicas a episodios de la historia de España muy recientes cuando se publica la novela, como pueda ser la crisis de la filoxera - a la que alude Baroja en el capítulo titulado «Alcolea del Campo»- que afecta al campo español a partir del último cuarto del siglo XIX y, por supuesto, la guerra hispano-norteamericana, de la que se habla en la sexta parte de la novela; pero no existe esa peculiaridad de la novela en clave — sin duda la más característica y a la vez la más comprometedora para el autor- que es la aparición de personajes basados en personalidades públicas y coetáneas al novelista. Exceptuando la hipotética identificación — jamás demostrada ni avalada por Baroja - de ese personaje de la bohemia madrileña que es Villasús con la persona del escritor Alejandro Sawa, el resto de personas en las que se puede haber inspirado el escritor vasco son, como ya hemos dicho, familiares cercanos y amigos de sus años como estudiante. Entre las personas que aparecen en el texto con otro nombre distinto del que tenían en la vida real no hay políticos, aristócratas, escritores, artistas u otro tipo de miembros de alta sociedad española del fin de siglo que pueden ser reconocidos por el lectorcomo si sucedería en el caso de una novela en clave prototípica, como muchas de las que se escriben en España durante la Restauración a partir de la descripción que de los personajes que nos ofrece Baroja. Por eso, y aunque es verdad que en El árbol de la ciencia encontramos varios personajes que 
son inequívocos trasuntos $-\mathrm{y}$ en esta identificación nos ayudan mucho las memorias del escritor- de personas reales con las que el autor tuvo contacto directo, nos inclinamos por situar la novela dentro del subgénero autobiográfico, pero sin ir un paso más allá y sin identificarla plenamente como un roman à clèf.

Por otra parte, y a pesar de que el mismo Baroja reconoce haber introducido cambios en el ambiente y en la familia de Andrés Hurtado con respecto a su ambiente familiar en la vida real, es precisamente ahí donde encontramos a estos personajes configurados a partir de referentes externos a la ficción. En don Pedro Hurtado y en su conflictiva relación con el protagonista de la novela ha querido ver Isabel Criado una traslación de los problemas paterno-filiales existentes entre Pío Baroja y su padre, Serafín Baroja (Criado, 1974: 32). En el caso de Luisito, el hermano pequeño de Hurtado, lo que vemos es un paralelismo evidente entre su historia y la de Darío, el hermano mayor del escritor, muerto igualmente de tuberculosis ${ }^{4}$. También se dan estas coincidencias en el caso de otros dos personajes de la novela: Julio Aracil y Montaner. Estos dos compañeros de Andrés Hurtado en sus estudios de Medicina no son otra cosa que la encarnación literaria de las personas de Carlos Venero (Julio Aracil) y Pedro Riudavets (Montaner), amigos de juventud y

\footnotetext{
${ }^{4}$ Con el caso del personaje de Luisito y la tuberculosis que éste padece en la novela ocurre algo similar a lo que ya hemos visto que sucede con Iturrioz: existen varias y contradictorias versiones sobre si es un personaje inspirado en uno u otro miembro de la familia Baroja. La mayor parte de la crítica ha afirmado que el escritor traslada a este personaje la enfermedad que tuvo en la vida real su hermano mayor, Darío Baroja, muerto de tuberculosis el 1894, a los 23 años de edad. Como se puede leer en la cita de sus memorias que he reproducido, la hermana de Pío Baroja confirma este extremo cuando habla de Luisito y dice que hay algo de ella misma en el personaje, pero que «la enfermedad de éste es la de mi hermano Darío» (Baroja, 1998: 198). Sin embargo, esta versión se contradice en parte con la que da Amparo Hurtado en el prólogo a la única edición de las memorias de Carmen Baroja, donde leemos lo siguiente: «A finales de 1902, Carmen Baroja cayó gravemente enferma de tifus. Pío Baroja, que asistía a su familia como médico, cuidó de su hermana día y noche, durante semanas. Narró la angustiosa espera de aquellos días en El árbol de la ciencia (1911), trasladando la enfermedad de su hermana a Luisito Hurtado, el hermano menor de Andrés Hurtado, alter ego del novelista» (Hurtado, 1998: 19). Lo más confuso de todo es que es la propia Amparo Hurtado la que unas páginas antes, y en ese mismo prólogo, escribe esto: «[...] éstos fueron años sombríos para toda la familia porque Darío, el mayor, se puso enfermo de tuberculosis y murió al cabo de veinte meses, en 1894, sin haber llegado a cumplir los veinticuatro años. Su muerte fue un golpe terrible para el clan Baroja, que abandonó de inmediato la ciudad de Valencia. Pío Baroja narraría más tarde, en El árbol de la ciencia (1911), la muerte de su hermano, transformándola en la muerte de Luisito Hurtado, un personaje literario que, como veremos, confeccionó a partir de Darío y de Carmen Baroja» (Hurtado, 1998: 15). Al margen de esta evidente contradicción, motivada quizá por ese confuso pasaje de las memorias de Carmen Baroja que cito en el texto, parece bastante claro que fue Darío, el hermano mayor del novelista muerto de forma prematura, quien padeció en vida la enfermedad que luego Baroja recrea en la novela valiéndose del personaje de Luisito, hermano pequeño de Andrés Hurtado.
} 
estudios de Baroja, de quienes el autor habla también en sus memorias. Cito solamente estos por poner los ejemplos que son más evidentes, pero podrían aportarse otros, unos más directamente identificables y otros más matizados o alterados, inspirados también en personas conocidas del autor.

Sobre la cuestión de si es uno - Andrés Hurtado- o son dos —Andrés Hurtado e Iturrioz - los personajes autobiográficos de la novela, me decanto personalmente por esta última opción. Si entendemos al personaje autobiográfico en el sentido más ortodoxo, como un trasunto de la persona real del autor que revive las situaciones anteriormente vividas por este y adopta en la novela sus actitudes y opiniones, creo sin duda alguna que el único personaje autobiográfico de la novela es el protagonista. Como seguidamente voy a demostrar con varios ejemplos extraídos de las memorias de Baroja y de $E l$ árbol de la ciencia, es Andrés Hurtado quien vive en la novela los años de juventud de Baroja. Con excepción del ambiente familiar, donde el autor introduce algunos cambios con respecto a su vida real, el resto de pasos que da el protagonista de la novela son los mismos que dio él mismo. Me refiero sobre todo a la experiencias vividas por Hurtado y Baroja durante los seis años como estudiantes de Medicina, compartiéndolos con unos compañeros de estudios y unos profesores que son los mismos en la novela y en la vida real; el viaje y estancia en Valencia y en un pueblo de los alrededores que hace Baroja y que luego reproduce en la novela, incluyendo el episodio de la muerte de su hermano (su hermano mayor Darío en la vida real y el hermano pequeño Luisito en la novela); o la estancia de Hurtado como médico rural en el pueblo de Alcolea del Campo, que es traslación del episodio real en la vida de Baroja que fue su estancia como médico en el pueblo vasco de Cestona. A todos estos datos empíricos se sumaría el hecho de que, bajo mi punto de vista, Andrés Hurtado es también un alter ego de Baroja, desde el momento en que reproduce los pensamientos y la actitud ante la vida que pudo tener Baroja durante los años que se corresponden con los del protagonista de la novela.

La identificación inequívoca del pensamiento de un autor con el del personaje de su novela siempre es problemática y difícil — por no decir imposible- por la misma naturaleza del texto: por muchas y muy evidentes coincidencias que se aprecien, no hay que perder de vista que lo que se pretende con esta identificación es establecer un lazo entre una persona real y un personaje de ficción. En este sentido, y hablando de esta inserción del pensamiento del autor en uno de sus personajes, la hispanista Roberta Johnson ha dicho que, a diferencia de lo que sucede en otros géneros como el artículo periodístico, el ensayo o el tratado, donde el discurso filosófico se identifica claramente «con la propia voz personal del autor», en el caso de la novela «ninguna de las voces $\mathrm{t}$ - tanto la primera o tercera persona narrativa como las voces de los personajes en diálogo o monólogo interior- se puede atribuir directamente al autor»(Johnson, 1997. 22). Aun admitiendo la validez del 
argumento, no creo que me impida defender el influjo del pensamiento barojiano en algunos de sus personajes. De hecho, vaya por delante ya que sí considero que en Andrés Hurtado se da ese autobiografismo ideológico, esa transmisión de las ideas del autor y de su concepción del mundo. Como síntoma y muestra de esta comunión de ideas entre el Baroja de juventud y el protagonista de la novela, se pueden cotejar las lecturas (novelas, libros de ensayo, historia, filosofía, etc.) que hizo el autor durante estos años y las que hace el personaje en la ficción; son exactamente las mismas (novelistas y folletines de autores franceses e ingleses, y filósofos como Kant, Fichte o Schopenhauer $)^{5}$. La importancia de estas lecturas en la formación del Baroja escritor y en la configuración de la visión del mundo y de la sociedad que tiene el protagonista de El árbol de la ciencia es tal que en esta investigación dedicaré un extenso apartado a destacar ese aspecto, que es también otra forma de autobiografismo materializada en esta imposición por parte del autor al protagonista de la ficción del mismo régimen de lecturas que él había seguido dos décadas antes.

El caso de Iturrioz es distinto, tanto en lo que se refiere a su función dentro de la novela, como en lo relativo a su grado de identificación autobiográfica con el autor. Desde el punto de vista narrativo, y teniendo en cuenta el tipo de presencia que tiene el personaje, siempre ligada a la figura de Andrés Hurtado como alguien que le escucha y le aconseja, podemos clasificar a Iturrioz dentro del grupo de aquellos personajes secundarios que ocupan posiciones relevantes en una trama novelesca actuando bien como antagonistas, bien como «adyuvantes» o personajes que participan de la acción y ejercen de informadores, confidentes o compañeros del protagonista. Según José R. Valles, el más destacado de este tipo de personajes adyuvantes sería aquél al que este teórico de la narrativa llama «confidente», en una definición que nos podría servir para el caso de Iturrioz en El árbol de la ciencia. El personaje confidente de una novela es para Valles «un tipo de adyuvante y, a veces, acompañante permanente del protagonista que tiene, más que relevancia actuacional, un destacado papel de interlocución de los pensamientos del protagonista» (Valles Calatrava, 2008: 166). Aunque es en la novela que nos ocupa donde esta función de Iturrioz cobra mayor importancia, este mismo personaje ya había aparecido anteriormente en La dama errante (1908) y en La ciudad de la niebla (1909) - las dos novelas de Baroja que integran junto con El árbol de la ciencia (1911) la trilogía «La raza»- ejerciendo un papel más o menos parecido como consejero o interlocutor del personaje principal.

La otra gran diferencia que presenta Iturrioz con respecto a Andrés Hurtado es que con él ya no estamos ante un caso de autobiografismo basado en la reproducción de episodios vitales del autor, sino que nos encontramos más

\footnotetext{
${ }^{5}$ En uno de los capítulos de mi tesis doctoral analizo en profundidad la relación existente entre los hábitos de lectura de Pío Baroja y Andrés Hurtado.
} 
bien ante un ejemplo muy claro de autobiografismo ideológico: de instrumentalización de un personaje como vehículo de transmisión del pensamiento y las opiniones del autor. Lo peculiar en Iturrioz es que, aparentemente, realiza una función que ya ha sido asumida en la novela por su protagonista; sin embargo, aquí la clave está en ese desdoblamiento autobiográfico. Teniendo en cuenta que, como he dicho, Baroja escribe El árbol de la ciencia cuando tiene entre 36 y 38 años, es evidente que el Baroja que escribe la novela ha cambiado y ha madurado con respecto a ese Baroja joven que representa Andrés Hurtado. De hecho, son más de dos décadas las transcurridas entre el momento en que el joven Pío Baroja empieza su carrera de Medicina (ése es el momento en que se inicia la acción en El árbol de la ciencia) y el momento en que se escribe la novela. Por esta misma razón, mi teoría es que Baroja se retrotrae mentalmente a esos años de juventud para recrearlos autobiográficamente - en hechos empíricos y en ideas - en el personaje de Andrés Hurtado, mientras que usa el personaje de Iturrioz como prolongación de su personalidad más madura, la que se está formando en el momento de escribir la novela. Así pues, en Iturrioz volcaría Baroja sus ideas más recientes; unas ideas más matizadas o sosegadas, más relativizadas o escépticas que las generadas por un ímpetu juvenil más acentuado y exacerbado como el de Andrés Hurtado. Con sus debidos matices, esta interpretación encaja bastante bien con la postura de aquellos críticos —entro los que me incluyo- que piensan que, grosso modo, la nómina de los personajes barojianos estaría formada por dos grandes grupos que responden básicamente a la clásica dicotomía acción/ contemplación de manera que, «o son sujetos contemplativos que reproducen el auténtico modo de ser del novelista o criaturas lanzadas a la acción por la acción, que reflejan lo que él hubiese deseado ser» (Sobejano, 2004: 357). El problema que presenta nuestra novela es que, en puridad, ninguno de los dos personajes principales se ajusta al segundo modelo. Pese a identificarlo con el Baroja de juventud, Hurtado no deja de ser un personaje eminentemente contemplativo, de los que se ajustan más a la biografía que conocemos del autor. En el caso de Iturrioz, y a pesar de su influencia nietzscheana y de que en algún pasaje de la novela aconseja a su sobrino la acción —eso sí, en un círculo limitado y reducido-, tampoco se puede decir de él que sea miembro de pleno derecho del grupo de personajes de acción barojianos que encarnan ese ideal de existencia aventurera - omo sí lo pueden hacer Eugenio de Aviraneta, Martín Zalacaín o Shanti Andía, por poner algunos ejemplosque al novelista le hubiese gustado vivir. Siendo, por tanto, dos personajes en los que domina más la faceta contemplativa que la activa, reitero que mi interpretación de la relación del autor con ambos personajes se acerca más a esa teoría que podríamos llamar «generacional», en el sentido de defender que cada uno de los personajes se asimilan a dos momentos distintos — juventud y madurez - de la vida y la tendencia ideológica del autor.

En sus escritos autobiográficos, Baroja habló siempre de dos posturas vita- 
les para cuya definición tomaba prestadas las categorías nietzscheanas de «lo dionisíaco» y «lo apolíneo» ${ }^{6}$ : la actitud dionisíaca, más propia de la juventud y de una personalidad inconformista e inclinada a la acción, y la concepción apolínea, basada en la virtud del equilibrio y la mesura, propia de una personalidad más madura y reposada. En un epígrafe de Juventud, egolatría precisamente titulado así, «¿Dionisíaco o apolíneo?», Baroja explicaba algo que encaja bastante bien con mi teoría, cuando decía que él siempre se había considerado a sí mismo como un dionisíaco (esto lo identifico con esos años de juventud recreados en la novela), pero que, cada vez más, notaba que ese ímpetu se iba calmando e iba dejando paso a la faceta de su personalidad más apolínea (faceta que para mí representa el personaje de Iturrioz en la novela):

Antes, cuando me creía un hombre humilde y errante, estaba convencido de que era un dionisíaco. Me sentía impulsado a la turbulencia, al dinamismo, al drama. Naturalmente, era anarquista. ¿Ahora lo soy? Creo que también. Entonces tenía entusiasmo y odiaba el pasado.

Poco a poco la turbulencia se ha ido calmando; quizá nunca fue grande; poco a poco he visto que si el culto de Dionysios hace moverse a saltos la voluntad, el culto de Apolo hace reposar la inteligencia sobre la armonía de las líneas eternas. $\mathrm{Y}$ en lo uno y en lo otro hay un gran atractivo (Baroja, 1997-1999, XIII: 343).

La máxima expresión de este contraste de ideas, de este choque entre esas actitudes a las que Baroja llamaba dionisíaca y apolínea, sería el diálogo entre ambos personajes, entre las dos posturas de Baroja (la de su juventud y la de una madurez alcanzada veinte años después), que ocupa la cuarta parte de la novela.

Sobre si en el resto de personajes de El árbol de la ciencia hay o no ejemplos de ese autobiografismo ideológico, pienso que puede haberlo, pero de forma mucho más limitada y casi anecdótica. Es cierto que Baroja puede usar a algunos de ellos para expresar, en un pasaje concreto de la novela, su opinión o parecer sobre tal o cual asunto, pero son situaciones aisladas y personajes siempre secundarios y planos. La única que se salva de esto es Lulú. En su discurso sí que puede haber un importante contenido de ideas barojianas, sobre todo en el sentido apuntado por algún crítico de expresión de las ideas del autor sobre el matrimonio y sobre la mujer en general. Sería un caso más en su obra, como lo es el de María Aracil en la novela La dama errante, de personaje femenino creado como ejemplo o modelo en el que se darían algunas de las virtudes o valores que el novelista más apreciaba en una mujer.

\footnotetext{
${ }^{6}$ He desarrollado este tema de forma monográfica en mi ensayo «Baroja por Baroja. Lo dionisíaco y lo apolíneo: Baroja par lui-même» (2012). Pasajes de pensamiento contemporáneo, 37, pp. 47-55.
} 


\section{EL «ESPACIO AUTOBIOGRÁFICO» BAROJIANO: MEMORIAS Y NOVELA}

Son múltiples los episodios vividos por Andrés Hurtado en la novela basados o inspirados en la vida real de Baroja y trasladados de forma casi literal a los textos autobiográficos del novelista. La mayoría de estos episodios, contados por primera vez en El árbol de la ciencia, son luego recogidos en «Familia, infancia y juventud», el segundo volumen de Desde la última vuelta del camino, las memorias que el escritor vasco empieza a redactar en 1941 y que publicará la editorial Biblioteca Nueva a lo largo de la década de los cuarenta.

Como sucede con la mayoría de textos que integran este género, las memorias de Baroja tienen sus propias especificidades $y$, sin ser en absoluto la parte de su producción que más debate ha suscitado, revisten un gran interés como documento literario y, sobre todo, como fuente preciosa para conocer la vida y la persona del escritor; además, incrementan nuestro conocimiento del contexto en el que vivió el autor y de la época histórica que de alguna manera reconstruyen $^{7}$. Lo que más se ha criticado y puesto en duda de las memorias barojianas ha sido justamente eso: el exceso de subjetividad y arbitrariedad en los juicios emitidos y, especialmente, el poco celo puesto por Baroja a la hora de ser preciso recordando datos o recreando situaciones que, según parte de la crítica, pasadas por el tamiz del recuerdo barojiano conservan poco de su verdad original. Algo así ha apuntado Sánchez-Ostiz en su biografía del novelista cuando escribe en relación con los volúmenes de Desde la última vuelta del camino que «al propio Baroja, tan celoso de la precisión del dato, las fechas, los nombres necesarios, las circunstancias precisas, le bailaban que eran un gusto, y puesto a contar, contaba lo que y como le daba la gana, y tal vez, solo tal vez, lo que le convenía» (Sánchez-Ostiz, 2006: 13).

No es difícil imaginar que no era esa la opinión de su autor. En el extenso prólogo a sus memorias y en previsión sin duda de las futuras críticas, Baroja explica y remarca una y otra vez su deseo de ser fiel a la realidad o, al menos, de no falsearla deliberadamente:

Yo no tengo por costumbre mentir. Si alguna vez he mentido, cosa que no recuerdo, habrá sido por salir de un mal paso. No por pura decoración. Los hechos de la vida están casi siempre tan conectados el uno con el otro, que el mentir para darse tono me parece una estupidez sin objeto.

[...] Respecto a la verdad de los hechos que yo cuento, yo la tengo por exacta; pero no me chocaría nada que muchos pequeños detalles estuvieran transformados por el recuerdo (Baroja, 1997-1999, I: 107).

Por otra parte, es importante también subrayar el hecho de que, contengan más o menos verdades y sean más o menos fiel a los hechos, las memo-

\footnotetext{
${ }^{7}$ Andrés Trapiello ha escrito que las memorias de Pío Baroja son «sin ningún género de duda, las memorias literarias más importantes en la literatura española, tanto por su contenido como por su extensión» (Trapiello, 1997: 135).
} 
rias de Baroja son un texto netamente autobiográfico, en el sentido de que cumplen - o esa es su intención- el «pacto autobiográfico» lejeuniano. De hecho, y como ha destacado Anna Caballé, Baroja es «el único de los escritores del 98 que nos ha legado unas Memorias de su vida, escritas ab initio con esa específica intención» (Caballé, 1995: 171). No se trata, pues, de una novela que a posteriori se ha leído como un texto autobiográfico, como sucede con El árbol de la ciencia, sino que es un texto concebido y reconocido como autobiográfico por el propio autor; es importante subrayarlo porque solo así - teniendo un texto autobiográfico y otro de ficción- es posible la interrelación de la que nace el «espacio autobiográfico»:

\footnotetext{
Voy a escribir esta especie de Memorias con la ilusión de que puedan ser interesantes. Yo espero que a alguno le entretendrán. Quizá me engañe. No pienso inventar nada, sino contar lo que recuerde, más o menos transformado por la memoria (Baroja, 1997-1999, I: 128).
}

Esto es lo dicho por Baroja sobre la veracidad o la intención de veracidad de sus memorias. Sin embargo, y en lo que es una de las especialidades del escritor vasco, en otro pasaje de sus memorias nuestro autor se contradice. $\mathrm{O}$ eso, o se considera a sí mismo como una excepción con respecto a todos aquellos a los que incluye en una regla general por él formulada: «Yo no sé si los que escriben recuerdos mienten a sabiendas o inconscientemente; pero que lo hacen, me parece indudable» (Baroja, 1997-1999, I: 700).

Ante la imposibilidad de comprobar en otras fuentes cada uno de los datos que da o de las anécdotas que cuenta Baroja en sus memorias, la postura más lógica y la que adopto en este trabajo es la de conceder a las memorias un nivel de fiabilidad lo suficientemente alto como para considerarlas un testimonio de valor y una versión de los hechos no interesada o maliciosamente manipulada. Verlo de otra forma sería considerar las memorias como una novela más, como una ficción entreverada con unas pocas verdades, y no creo que sea esta la postura más adecuada que puede adoptar el lector ante unas memorias que ocupan más de dos mil páginas. No considero que en las memorias del escritor haya tantos datos tergiversados; como sucede con otros aspectos de su obra y personalidad, creo que la imagen de Baroja como la de un «mentiroso compulsivo» que no decía una sola verdad tiene también su cuota importante de tópico, de mito creado por la crítica exagerando el poder de imaginación y la sed de venganza de Baroja para con aquellos — que son bastantes, eso es cierto- que salen mal parados en los juicios que emite el autor en sus memorias. En cambio, sí creo que puede haber bastantes errores, lapsus o imprecisiones en datos, fechas, etcétera. No hay que olvidar que Baroja escribe y publica sus memorias cuando tiene entre setenta y ochenta años y empieza a sufrir las consecuencias de la dura enfermedad - la arterioesclerosis- que finalmente acabará con su vida; por buena memoria que tuviese, es evidente y comprensible la existencia de olvidos o confusiones en 
alguien que recuerda lo vivido hace ya más de medio siglo. Como explica Anna Caballé, es evidente que todo esto afecta a la calidad y a la forma de las memorias y que «a la desestructuración de la obra hay que añadir las consecuencias de frecuentes lapsus mentis sufridos por el novelista, que se reflejan en una escritura de esquema circular y reiterativo» (Caballé, 1995: 174).

Pese a que no es mi intención la de hacer un cotejo exhaustivo entre una versión — la de la memorias - la otra — la de la novela que nos ocupa- de los hechos, porque se me antoja absurdo y porque el mayor o menor grado de semejanza y fidelidad entre las memorias y la novela no afecta en nada a la postura aquí defendida, sí que quiero citar algunos ejemplos concretos de esta coincidencia textual entre El árbol de la ciencia y las memorias de Pío Baroja para certificar la existencia dentro del conjunto de la obra del escritor de ese «espacio autobiográfico» al que ya he aludido. Cito solamente algunos pasajes que evidencian el carácter autobiográfico del protagonista de la novela. La mayoría de estas coincidencias se encuentran en el capítulo de las memorias titulado «De estudiante de medicina» y en la primera mitad de la novela.

La primera escena de El árbol de la ciencia describe las sensaciones que experimenta Andrés Hurtado en su primer día como universitario. Esto leemos en la primera página de la novela:

La clase de química general del año preparatorio de medicina y farmacia se daba en esta época en una antigua capilla del Instituto de San Isidro, convertida en clase, y ésta tenía su entrada por la Escuela de Arquitectura.

La cantidad de estudiantes y la impaciencia que demostraban por entrar en el aula se explicaba fácilmente por ser aquél el primer día de curso y del comienzo de la carrera.

Ese paso del bachillerato al estudio de facultad siempre da al estudiante ciertas ilusiones, le hace creerse más hombre, que su vida va a cambiar.

Andrés Hurtado, algo sorprendido de verse entre tanto compañero, miraba atentamente, arrimado a la pared, la puerta de un ángulo del patio por donde tenía que pasar (Baroja, 1997-1999, VIII: 373).

Así describe la misma escena Baroja en sus memorias, escritas y publicadas más de treinta años después. Nótese el ligero cambio que supone eliminar el nombre del protagonista de la novela e introducir la primera persona. Lo demás es idéntico en la novela y en las memorias:

La clase de química general del año preparatorio de medicina y farmacia se daba en esta época en una antigua capilla del Instituto de San Isidro, convertida en clase, y ésta tenía su entrada por la Escuela de Arquitectura. En esta sala se había celebrado el juicio contra el general don Diego de León, en 1841, durante la regencia de Espartero.

Para llegar a esta clase se pasaba por un patio.

Recuerdo la cantidad de estudiantes y la impaciencia que demostraban por entrar en el aula una mañana de octubre, lo que se explicaba fácilmente por ser aquél el primer día de curso y del comienzo de la carrera. 
Ese paso del bachillerato al estudio de facultad siempre da al estudiante ciertas ilusiones, le hace creerse más hombre, que su vida va a cambiar. Yo, algo sorprendido de verse entre tanto compañero, miraba atentamente, arrimado a la pared, la puerta de un ángulo del patio por donde tenía que pasar (Baroja, 19971999, I: 474).

Veamos la descripción que hace Andrés Hurtado en la novela de su compañero de estudios, Julio Aracil:

Aracil era un poco petulante; se cuidaba el pelo, el bigote, las uñas y le gustaba echárselas de guapo. Su gran deseo en el fondo era dominar, pero no podía ejercer su dominación en una zona extensa, ni trazarse un plan, y toda su voluntad de poder y toda su habilidad se concentraba en cosas pequeñas. Hurtado le comparaba a esos insectos activos que van dando vueltas a un camino circular con una decisión inquebrantable e inútil.

Una de las ideas gratas a Julio era pensar que había muchos vicios y depravaciones en Madrid (Baroja, 1997-1999, VIII: 395).

Leamos ahora la que hace Baroja en las memorias de su también compañero de estudios e inspirador del personaje literario, Carlos Venero:

Venero era un poco petulante; se cuidaba el pelo, el bigote, las uñas y le gustaba echárselas de guapo. Su gran deseo en el fondo era dominar, pero no podía ejercer su dominación en una zona extensa, ni trazarse un plan, y toda su voluntad de poder y toda su habilidad se concentraba en cosas pequeñas. Una de las ideas gratas para él era pensar que había muchos vicios y depravaciones en Madrid (Baroja, 1997-1999, I: 471).

Otros personajes/personas presentes en ambos textos son algunos de los profesores que tuvo Baroja durante la carrera y de los que habla por boca de Andrés Hurtado en El árbol de la ciencia, para luego reproducir estos juicios en sus memorias. Esta es la opinión de Andrés Hurtado sobre el profesor José de Letamendi:

El año siguiente, el cuarto de la carrera, había para los alumnos, y sobre todo para Andrés Hurtado, un motivo de curiosidad: la clase de don José de Letamendi.

[...] Letamendi era un señor flaco, bajito, escuálido, con melenas grises y barba blanca. Tenía cierto tipo de aguilucho: la nariz corva, los ojos hundidos y brillantes. Se veía en él un hombre que se había hecho una cabeza, como dicen los franceses. Vestía siempre levita algo entallada, y llevaba un sombrero de copa de alas planas, de esos sombreros clásicos de los melenudos profesores de la Sorbona.

En San Carlos corría como una verdad indiscutible que Letamendi era un genio; uno de esos hombres águilas que se adelantan a su tiempo; todo el mundo le encontraba abstruso porque hablaba y escribía con gran empaque un lenguaje medio filosófico, medio literario (Baroja, 1997-1999, VIII: 397-398). 
Así lo describe Baroja en las memorias; como se aprecia, es el mismo recuerdo:

Al comenzar el cuarto año de la carrera y tercero dentro de San Carlos, había para los alumnos un motivo de curiosidad: la clase de don José Letamendi.

[...] Letamendi, cuando yo le conocí, era un señor flaco, bajito, escuálido, con melenas grises y barba blanca. Tenía cierto tipo de aguilucho: la nariz corva, los ojos hundidos y brillantes. Se veía en él un hombre que se había hecho una cabeza, como dicen los franceses. Vestía siempre levita algo entallada, y llevaba un sombrero de copa de alas planas, de esos sombreros clásicos de los antiguos y melenudos profesores de la Sorbona, y bastón.

En San Carlos corría como una verdad indiscutible que Letamendi era un genio, uno de esos hombres águilas que se adelantan a su tiempo. Todo el mundo le encontraba abstruso porque hablaba y escribía con gran empaque un lenguaje medio filosófico, medio literario (Baroja, 1997-1999, I: 503).

Y como último ejemplo reproduzco la descripción que hace Andrés Hurtado del personaje de Juan Sánchez, el otro médico de Alcolea del Campo con el que tendrá problemas en la novela durante su convivencia en el pueblo:

Don Juan Sánchez había llegado a Alcolea hacía más de treinta años de maestro cirujano; después, pasando unos exámenes, se llegó a licenciar. Durante bastantes años estuvo, con relación al médico antiguo, en una situación de inferioridad, y cuando el otro murió, el hombre comenzó a crecerse y a pensar que ya que el tuvo que sufrir las chismorrerías del médico anterior, era lógico que el que viniera sufriera las suyas.

Don Juan era un manchego apático y triste, muy serio, muy grave, muy aficionado a los toros. No perdía ninguna de las corridas importantes de la provincia, y llegaba a ir hasta las fiestas de los pueblos de la Mancha baja y de Andalucía (Baroja, 1997-1999, VIII: 493).

En la vida real, el personaje inspirador de este médico se llamaba Pedro Díaz. Con él fue con quien tuvo problemas Baroja durante el año y poco que estuvo como médico en la localidad vasca de Cestona. Como se aprecia en la descripción de las memorias, uno y otro médico son el mismo:

Tuve rivalidades, de las cuales creo que no fui yo el iniciador, con el otro médico, que se llamaba Pedro Díaz. Éste había llegado a Cestona hacía más de treinta años, de maestro cirujano del ejército carlista; después, pasados unos exámenes, se llegó a licenciar.

Durante bastante tiempo estuvo Díaz, con relación al otro médico, Umerez, en una situación de inferioridad, y cuando el otro murió, el hombre comenzó a crecerse y a pensar que ya que él tuvo que sufrir las chinchorrerías del anterior, era lógico que le que viniera sufriera las suyas.

Díaz era de la parte castellana de Álava, hombre muy dogmático y muy aficionado a los toros; no perdía ninguna de las corridas importantes que se celebraban en San Sebastián (Baroja, 1997-1999, I: 579-580).

Aunque este curioso mecanismo consistente en copiar de la ficción de $E l$ árbol de la ciencia lo que después presentará como episodios reales de su vida 
en sus memorias pueda sorprender al lector, hay que decir que se trata de un mecanismo habitual en Baroja (ya he citado antes algunas de las novelas de las que el autor extrae su material autobiográfico). Como escribe Sebastián Juan Arbó en su biografía del novelista vasco, «cuando Baroja quiso escribir sus Memorias no tuvo más que espigar en su obra y trasladar sin apenas tocar nada. Entonces nos hemos dado cuenta de la cantidad de autobiografía que había sembrado en ella. Su Árbol de la ciencia, por ejemplo, ha sido trasladado casi entero a sus Memorias...» (Arbó, 1963: 777). Y lo más curioso de todo es que no se precisa ninguna investigación detectivesca para llegar a esta conclusión; primero porque resulta palmaria para quien ha leído ambos textos, y segundo porque ya en el prólogo de sus memorias es el propio Baroja quien lo anuncia con toda tranquilidad y franqueza, para que nadie pudiera hacerse luego el sorprendido o el estafado pensando que iba a encontrar nuevas y secretas revelaciones:

Otra cosa que tengo que advertir es que pienso copiarme a veces a mí mismo y utilizar párrafos de otros libros, porque algo dicho con claridad y sinceridad una vez, yo creo que no se puede cambiar ni se puede mejorar fácilmente.

Voy a coger de mis novelas todo lo que tenga aire autobiográfico y darlo junto en el mismo libro (Baroja, 1997-1999, I: 117).

Efectivamente, eso es lo que hace el escritor y lo que, unido a la forma en la que concibe sus memorias, como una acumulación de datos, anécdotas y opiniones que no tienen principio ni fin y que solamente siguen un orden cronológico (a veces ni eso), hace que no podamos hablar de Desde la última vuelta del camino como de un texto homogéneo y unitario, en el sentido más ortodoxo. Como ha subrayado Anna Caballé, las memorias barojianas pueden ser vistas como un «texto-río, que discurre por los meandros de una memoria oscilante» y en el que «la escritura de la mayor parte de los capítulos se funda en una acumulación de textos anteriores y acontecimientos que se retoman y reformulan en repetidas ocasiones a lo largo de los siete volúmenes» (Caballé, 1995: 172). Según Biruté Ciplijauskaité, es también este reaprovechamiento de materiales lo que habría provocado el menor interés despertado por las memorias de Baroja si lo comparamos con la atención que han recibido sus mejores novelas por parte de la crítica. Esta repetición de informaciones y opiniones ya vertidas en sus novelas sería la responsable de restar atractivo a unos textos autobiográficos que, pese a ello, lo siguen manteniendo:

\begin{abstract}
«Desde la última vuelta del camino», producto de madurez e incluso de vejez (el autor iba acercándose a los ochenta cuando se publicó el último volumen), es tal vez la obra menos comentada de Baroja. Esto puede ser debido al hecho de que no presenta en realidad nada radicalmente nuevo. Es más bien un compendio y la autentificación de todos los escritos barojianos, los cuales se distinguen por no delimitar rígidamente los géneros (Ciplijauskaité, 1997: 71).
\end{abstract}

En esta misma línea, pero con un sentido distinto, irían unas palabras que Josep Pla dedicó en su día a Baroja en las que se lamentaba del hecho de que 
el escritor vasco hubiese preferido ser más novelista que memorialista, aunque también hubiese escrito ya al final de su vida unas memorias. Para Pla, Baroja habría fracasado estrepitosamente como novelista porque lo mejor de sus novelas fue precisamente lo más autobiográfico y menos ficcional que hay en ellas: las memorias que se esconden detrás de cada una de esas ficciones, como las que pueden haber detrás de El árbol de la ciencia si leemos la novela en esta clave autobiográfica. Lo más chocante y crudo del severo juicio de Pla a la obra de Baroja es el hecho de que lo considerara tan pésimo novelista como excelso contador de memorias:

Baroja es un inmenso escritor. Pero se equivocó de técnica. Escribió novelas. Como novelas, sus novelas son ridículas. No conoció ni los trucos ni las triquiñuelas, ni la manera escandalosa de componer sus novelas que tienen los novelistas. Desde el punto de vista de la técnica de la novela — como en tantos otros aspectos de su vida-, Baroja fue un niño.

[...] Baroja, enorme escritor antibarroco, hubiera podido ser el mayor memorialista de la literatura castellana de todos los tiempos. Cuando sus obras se reducen a lo que son en realidad, a una sucesión de paisajes, de figuras y de ambientes, tienen una calidad sensacional, única, insuperable, magnífica. Cuesta, sin embargo - y esto produce fatiga - , eliminar de estos libros lo que tienen de tripa inútil, de intriga ficticia, de truco añadido, de peluquería novelística. Lo que el escritor pone directamente de su asombro ante el mundo, es de primera calidad. Cuando, sobre todo, quiere montar con penas y fatigas, una intriga aparentemente vendible - que no fue jamás vendible - el esfuerzo decae y aparece la pura inanidad. Y esto perjudica a aquello. Sin estas adiposidades de la escenografía literaria, Baroja hubiera podido llegar a ser el mayor testigo presencial de la vida de su tiempo en la Península Ibérica. Baroja hubiera podido ser el Saint-Simon del mundo ibérico del siglo XX si en lugar de escribir novelas de corte infantil hubiera escrito unas interminables -o concentradas - memorias de su vida. Se equivocó de técnica. Sus libros mayores son en todo caso los memorialísticos (Pla, 1961-1962: 347-348).

Sea como fuere y se esté o no de acuerdo con estas opiniones, lo evidente es que de este cruce de referencias y de informaciones que confirman o se contradicen entre El árbol de la ciencia y las memorias de Pío Baroja nace un vínculo o terreno intermedio y difuso entre géneros, entre lo ambiguo de la ficción y lo supuestamente preciso de la autobiografía, que nos permite hablar perfectamente de la posibilidad que ofrece la obra de Baroja para que sea el lector quien cree ese «espacio autobiográfico».

En este sentido, considero que existen los argumentos necesarios para afirmar que el lector de El árbol de la ciencia puede crear, con la ayuda de las memorias de Baroja, un «espacio autobiográfico» que, si bien no le aporta más calidad a la novela, si que enriquece mucho su comprensión y dota a la lectura de mayor profundidad y de un valor añadido como fuente para conocer al novelista y, por lo que nos interesa aquí, como fuente para conocer el contexto vital en el que se movía. De este modo, podemos ver si alguna de las opiniones sobre la sociedad de su época vertidas por Andrés Hurtado en la novela pueden tener alguna relación o implicación con determinados sucesos 
o condicionantes de la vida de Baroja. Por otra parte, y como ya he expresado, la creación de este «espacio autobiográfico» requiere como premisa nuestra confianza en la veracidad - $\mathrm{O}$ al menos en la no falsedad- de unos escritos de Baroja que nos permiten conocerle más y que avalan, mediante su cotejo con las novelas, esta lectura autobiográfica del conjunto de su obra.

Por todos estos motivos, pienso que esa es justamente la ventaja que aporta al lector de El árbol de la ciencia la lectura de las memorias: la creación de un «espacio autobiográfico» en el que quizá se entiendan muchas cosas que de otra forma y con la sola lectura de la novela no se entenderían, o no se entenderían tan bien.

\section{LA DOBle NATURALEZA DE ANDRÉS HuRtAdo: LO AUTOBIOGRÁfico Y LO GENERACIONAL}

Repasados los argumentos a favor de una identificación autobiográfica entre la persona de Pío Baroja y el personaje de Andrés Hurtado, cabe por último matizar o ampliar esta visión con otro aspecto o valor de la novela que resulta necesario para acabar de completar mi conclusión sobre la naturaleza de su personaje protagonista y de la historia que vive en la ficción barojiana.

En principio, hay que recordar que esta lectura en clave autobiográfica se hace siempre atendiendo a las coincidencias que ya hemos visto que se dan entre el texto de ficción de El árbol de la ciencia y el texto autobiográfico de las memorias de Baroja, y también atendiendo a las declaraciones o afirmaciones que a lo largo de su vida hizo Baroja en el sentido de confirmar o reafirmar este vínculo personal con algunos de los personajes de sus creaciones novelísticas y que actúan como una especie de «garantías» de veracidad o de sentido de esa creación —el «espacio autobiográfico»- que se hace el lector de la novela. No obstante todo esto, sabemos también que en algunos aspectos de la novela esta identificación no se cumple a rajatabla, no se da al cien por cien en su contenido, ya sea por interés del autor en modificar la versión real de los hechos, ya sea porque es la propia trama novelística la que lleva al personaje por otros derroteros distintos. En cualquier caso, lo cierto es que el alto nivel de autobiografismo de la novela no implica una reducción extrema que limite la vida de su protagonista a una simple reproducción de la existencia del autor, ni mucho menos. Dentro de la novela, Andrés Hurtado también tiene su vida propia como creación literaria independiente de su autor. Hurtado se comporta muchas veces como se comporta Pío Baroja, pero no es Pío Baroja; el protagonista de la novela actúa como actuó - en el caso de las vivencias pasadas de cuya existencia dan fe las memorias del novelista - el autor o como inferimos que podría actuar este - y me refiero ahora al «autobiografismo ideológico» del personaje- si viviera las mismas situaciones que vive el personaje en la novela. 
De acuerdo con lo expuesto en su día por Mijaíl Bajtin, el alto grado de veracidad y realismo del mundo representado en la novela no implica jamás la identificación — «desde el punto de vista cronotópico» dice el crítico literario ruso- de este mundo con el mundo real en el que vive el «autor-creador» de esa representación. Por ello, concluye certeramente Bajtin, el lector de una novela — de El árbol de la ciencia en mi caso- puede, a partir de su lectura, crearse una imagen del autor, pero lo que no puede hacer nunca es, a partir de esta lectura suya y de sus conocimientos sobre el autor, tratar de incorporar por la fuerza la figura del autor dentro del entramado de la novela:
Naturalmente, el oyente-lector puede crear él mismo para sí una imagen del au- tor (y generalmente la crea; es decir, se imagina de alguna manera al autor): pue- de para ello, utilizar el material autobiográfico y biográfico, estudiar la época en la que el autor ha vivido y creado, así como otros materiales acerca del mismo; pero él (oyente-lector), tan sólo crea una imagen artístico-histórica del autor, que puede ser más o menos verídica y seria, es decir, sometida a los criterios que, generalmente, se aplican en tales casos a esas imágenes; pero que, naturalmente, no puede incorporarse al entramado imaginario de la obra. Sin embargo, si esa imagen es verídica y seria, le ayudará al oyente-lector a entender con más exac- titud y profundidad la obra del autor en cuestión (Bajtin, 1989: 407).

Estoy totalmente de acuerdo con esta idea bajtiniana que, aplicada al caso que aquí he querido analizar, confirma la importancia que le concedo al conocimiento de la biografía de Baroja y de sus Obras Completas; como dice Bajtin, una cosa no quita la otra y la imposibilidad de inscribir al autor en una trama de ficción no resta valor a la ayuda que supone para el lector el formarse una imagen del autor, cuanto más completa, mejor.

Pero volviendo a lo que he planteado en este apartado final, lo que pretendo con este último apunte no es negar el autobiografismo del personaje de Andrés Hurtado que vengo defiendo con argumentos, indicios y pruebas sino, contrariamente, darle un nuevo valor al personaje, un segundo sentido que se une a este primero ya analizado. El interés de la figura literaria de Andrés Hurtado para entender la personalidad de Pío Baroja - viceversa- me parece indiscutible. En este sentido, quizá haya sido Isabel Criado, quien considera El árbol de la ciencia como una novela clave y axial en la producción barojiana, la que más haya insistido en la propuesta de una interesante y sugerente teoría que defiende la validez de El árbol de la ciencia como lugar donde encontrar verbalizado a través de su personaje protagonista aquello que Baroja no siempre se atrevió a contar de forma clara en sus escritos reconocidamente autobiográficos:

[...] El árbol de la ciencia es el replanteamiento más radical que Pío Baroja hace de su vida: la realidad y el fracaso se presentan con absoluta desnudez y sinceridad. En algunos aspectos, Andrés Hurtado es más Pío Baroja que Baroja mismo, porque lo que el hombre ordinariamente oculta, en momentos de angustiosa crisis vital, lo expresa. Repetidamente he acudido a Hurtado para interpretar a Baroja, y repetidamente estoy definiendo a Hurtado como el fin de la individuación existencial de Baroja (Criado, 1974: 323). 
Pero creo que la importancia y la representatividad del personaje y, por extensión, de la novela, van mucho más allá y no se limitan al valor autobiográfico, que ya es mucho, como testimonio del sentir de un intelectual que vive la crisis de fin de siglo en la sociedad española. Aunque sin profundizar mucho en ello, en su completo estudio sobre la obra barojiana, Mary Lee Bretz ya reparaba en el hecho de que en nuestra novela «Andrés alcanza un valor más allá de su parentesco ideológico con Baroja; aparte su importancia como trasunto del escritor, está dotado de personalidad propia, es así, a la vez, agente independiente y personaje autobiográfico...» (Bretz, 1979: 392). Algo más explícito y más cercano a la idea que quiero expresar como conclusión a este repaso de lo autobiográfico en El árbol de la ciencia es Sergio Beser en el libro o guía de lectura que escribió sobre la novela. Concluye allí Beser que «la figura de Andrés Hurtado es fundamentalmente resultado de la integración de tres líneas confluyentes — vida del autor, testimonio generacional y pensamiento de Schopenhauer-, correspondientes a vivencias, actitudes, pensamientos o incidencias biográficas de Baroja» (Beser, 1983: 87).

Reduciendo estas tres líneas o vectores a solamente dos, porque considero que la faceta de Hurtado como expresión del pensamiento de Schopenhauer puede entrar perfectamente en las otras dos (Schopenhauer es un autor fundamental en la biografía de Baroja y también es un referente para toda la generación de intelectuales que viven la crisis de fin de siglo, en España y en Europa), mi propuesta para una primera definición o aproximación a la figura de Andrés Hurtado sería la de afirmar la existencia en él de una doble naturaleza: como trasunto del autor de la novela y como representante de toda una generación de jóvenes españoles que vivieron la crisis finisecular. Así pues, al valor autobiográfico del personaje como instrumento o vehículo de transmisión de las ideas y las experiencias del autor, se sumaría un segundo valor que le viene dado a Hurtado por la capacidad de Baroja para condensar en él las aspiraciones, anhelos y desencantos de esos jóvenes con inquietudes intelectuales que vivieron su particular crisis de valores dentro de la crisis cultural que afectó a la España y la Europa de fin de siglo. Desde este punto de visto, mi teoría es que en El árbol de la ciencia se da una suerte de juego dialéctico entre lo individual y lo social, lo autobiográfico y lo generacional, lo personal y lo colectivo, de modo que la obra deja de ser una novela estrictamente autobiográfica para convertirse, según la tesis que defiendo, en una magnífica fuente para el historiador interesado en estudiar la crisis de fin de siglo española.

\section{BIBLIOGRAFÍA CITADA}

Abellán, José Luis (1973). Sociología del 98. Barcelona: Ediciones Península.

Alberca, Manuel (2007). El pacto ambiguo: de la novela autobiográfica a la autoficción. Madrid: Biblioteca Nueva. 
Arbó, Sebastián Juan (1963). Pío Baroja y su tiempo. Barcelona: Editorial Planeta.

Azorín [José Martínez Ruíz] (9-IV-1918). «Nueva novela de Baroja», La Vanguardia.

Bajtin, Mijaíl (1989). Teoría y estética de la novela. Traducción de Helena S. Kriúkova y Vicente Cazcarra. Madrid: Taurus.

Baroja, Carmen (1998). Recuerdos de una mujer de la Generación del 98. Barcelona: Tusquets.

Baroja, Pío (1997-1999). Obras Completas, dirigidas por José-Carlos Mainer. Barcelona: Galaxia Gutenberg / Círculo de Lectores.

Basanta, Ángel (1980). La novela de Baroja. El esperpento de Valle-Inclán. Madrid: Cincel.

Beser, Sergio (1983). El árbol de la ciencia. Pío Baroja. Barcelona: Laia.

Bretz, Mary Lee (1979). La evolución novelística de Pío Baroja. Madrid: José Porrúa.

Caballé, Anna (1995). Narcisos de tinta. Ensayo sobre la literatura autobiográfica en lengua castellana (siglos XIX y XX). Málaga: Megazul.

Ciplijauskaité, Biruté (1997). «Introducción», en Pío Baroja, Desde la última vuelta del camino, OC. Vol. I, pp. 71-88.

Criado, Isabel (1974). Personalidad de Pío Baroja: trasfondo psicológico de un mundo literario. Barcelona: Planeta.

Torre, Guillermo de (1969). Del 98 al Barroco. Madrid: Gredos.

Río, Ángel del y M. J. Benardete (1946). El concepto contemporáneo de España. Antología de ensayos (1895-1931). Buenos Aires: Losada.

Durán, Manuel (1972). «El Baroja esencial: El árbol de la ciencia». Ínsula, 308-309, pp. 1, 14 y 15.

Ebanks, Gerardo (1974). La España de Baroja. Madrid: Ediciones Cultura Hispánica.

Fernández, Pura (2005). «La novela de clave en la Restauración o la literatura en pos de la verdad histórica». Studi Ispanici. Vol. 1, pp. 103-126.

Fernández Urbina, José Miguel (1998). Los vascos del 98: Unamuno, Baroja y Maeztu (juicios, actitudes e ideas ante la modernidad). San Sebastián: Bermingham.

Gaziel [Agustí Calvet] (27-II-1925). «El error de Baroja», La Vanguardia.

Granjel, Luis S. (1953). Retrato de Pío Baroja. Barcelona: Barna.

Hurtado, Amparo (1998). «Prólogo», en Carmen Baroja. Recuerdos de una mujer de la Generación del 98. Barcelona: Tusquets, pp. 9-36.

Johnson, Roberta (1997). Fuego cruzado: filosofía y novela en España (1900-1934). Traducción de Teresa Fernández. Madrid: Ediciones Libertarias

Mainer, José-Carlos (1997). «La sustancia barojiana», en Pío Baroja, Obras Completas, dirigidas por José-Carlos Mainer. Vol. I. Barcelona: Galaxia Gutenberg / Círculo de Lectores, pp. 11-62.

Medrano, Javier (2006). «Técnicas literarias en El árbol de la ciencia», en VV.AA, Pío Baroja: creación, conocimiento y vida. Vol. I. A la busca de Pío Baroja. Pamplona: Universidad Pública de Navarra, pp. 309-330.

Pla, Josep (1961-1962). «Pío Baroja», en Fernando Baeza (ed.), Baroja y su mundo. Tomo II. Madrid: Arión, pp. 347-349.

Salazar, Javier (1994). «El autor en su doble: don Pío Baroja y El árbol de la ciencia». Epos. Revista de filología. 10, pp. 261-298.

Sánchez-Ostiz, Miguel (2006). Pío Baroja, a escena. Madrid: Espasa Calpe.

Valles Calatrava, José R. (2008). Teoría de la narrativa. Una perspectiva sistemática, Madrid: Iberoamericana / Vervuert.

Fecha de recepción: 22 de marzo de 2012

Fecha de aceptación: 26 de julio de 2012 